\title{
PRIVATE SECONDARY EDUCATION IN EX-YU COUNTRIES AND MANAGEMENT PRACTICE IN PRIVATE SECONDARY SCHOOLS
}

\section{Bojan Ristic}

Information Technology School, Belgrade, Serbia

\section{Svetlana Andjelic}

Information Technology School, Belgrade, Serbia

\section{Valentin Kuleto}

Information Technology School, Belgrade, Serbia

\section{CMESTE}

JEL Category: 121, M12

\begin{abstract}
Private education business, as a specific category of private business, has been presented for a long time in the developed countries of the EU. In recent years this type of secondary education has been expanding also the ex-Yu countries. In comparison with the European Union, the management of private secondary schools in Serbia is also burdened with various problems. (No) the compliance of legal framework, somewhat dull strategy of education and outdated national qualifications frameworks imply a great medley in the said sphere of education, both in the public and in the non-public sector. In such situations, management of private schools is necessarily realized in analogous (apparently identical) manner as in public high schools. However, such a management model of private high schools is unacceptable as it severely limits the rights of the founder, as the subject who has invested capital in the school and that by that logic takes care of the development of the school and settle any losses in the business of the school. This paper aims to show the picture of private secondary education in ex$Y U$ countries. There are shown the results of research on management of private secondary schools conducted in Serbia and that of a sample consisting of persons who are directly engaged in private secondary education.
\end{abstract}

Keywords: private school; public (static) school; public school to private ownership; secondary school

Address of the corresponding author:

Bojan Ristić

莑=” bojan.ristic@its.edu.rs

\section{INTRODUCTION}

By its universal implications, the implementation and treatment of market economy also included the area of all levels and types of education. This 
is particularly reflected in the structures of control of educational institutions and payments to the cost of education. As for the structure of control, it should be noted that today in most countries, schools are managed by their founders, which include: the state (for public schools) and legal and natural persons (for private schools). On the other hand, when it comes to paying the costs of education, it should be noted that the public schools today are primarily funded by combinations of budget funds and payments by the participants in education, while in private schools cost of education are defrayed exclusively by the participants.

An eligible common feature of the educational system of the EU is the legal foundation of the non-state education. Laws have provided the opportunity for individuals, institutions, churches, associations to open schools at all levels of education. The work of schools is based on established standards which are usually approved or recognized by the Ministry of Education. The biggest differences are in terms of financing schools. Practically in most countries, state participates in part in the financing and, especially of direct participants in education. About holders of managing private school, their status is treated differently in the EU.

\section{STATISTICAL INDICATORS - EX YU AREA}

\subsection{General overview of the number of secondary schools}

All statistical data relating to the number of schools and the number of children in schools relate to the end of the school year 2014/15 and beginning of 2015/16 year because there are no recent data on the official websites Bureau of Statistics and the relevant ministries.

In the former Yugoslavia (ex Yu) there are 1612 secondary schools, mostly in Croatia, 707 (Upper Secondary Schools, End of 2014/2015 School Year and Beginning of 2015/2016 School Year, Croatia, 2016), Serbia 506 (Municipalities and regions in the Republic of Serbia, 2015 Education, 2015), Federation of Bosnia and Herzegovina $(\mathrm{BiH}) 200$ (Directory of secondary schools in the Federation of Bosnia and Herzegovina, 2012), followed by Macedonia 118
(Primary, lower secondary and upper secondary schools at the begining of the school year 2015/2016, Macedonia, 2016), Montenegro 50 schools (List of high schools in Montenegro, -) and at the end, Slovenia with only 31 high schools (Participants (youth and adults) in public and private upper secondary schools, Slovenia, annually, 2014). Of course that these figures significantly affect the size of the country itself, but primarily the size of the population or population which is certainly a relevant factor. Thus, the ratio of the number of inhabitants and the number of secondary schools is smallest in Croatia and Serbia, followed by Macedonia and Bosnia and Herzegovina, and at the bottom are Montenegro and Slovenia. That is, Croatia has the most secondary schools per capita, while in Slovenia there are at least schools per capita.

\subsection{Secondary schools - Public vs. Private}

According to the property, secondary schools occur in the following forms: public (government) and private. In addition to these types, there are public schools which are privately owned (as in Croatia and Slovenia). Private schools can be owned by commercial entities and/or individuals, also in Croatia and B\&H, there are private schools founded by religious communities. Most of these schools are located in $\mathrm{B} \& \mathrm{H}$.

In order to facilitate comparison of data, in the future work will be considered two categories of secondary schools: public and private. In the category of private schools are counted: private, public to private ownership, as well as private founded by religious communities.

At the end of the school year 2014/2015 the largest number of private secondary schools in relation to the number of public secondary schools in the ex YU teritory by far was in $\mathrm{B} \& \mathrm{H}$ $(25.50 \%)$ (Haskić, 2015), afterwards in Macedonia (12.07\%) (Primary, lower secondary and upper secondary schools at the begining of the school year 2015/2016, Macedonia, 2016), Serbia (109.67\%) (Municipalities and regions in the Republic of Serbia, 2016 - Education, 2017) (Srednje škole, Edukacija, -), Croatia (8.77\%) (Upper Secondary Schools, End of 2014/2015 School Year and Beginning of 2015/2016 School Year, Croatia, 2016) in the end in Slovenia 
(6.45\%) (Participants (youth and adults) in public and private upper secondary schools by type of education, Slovenia, annually, 2014) and Montenegro $(4.00 \%)$ (List of high schools in Montenegro, -) (Figure 1).

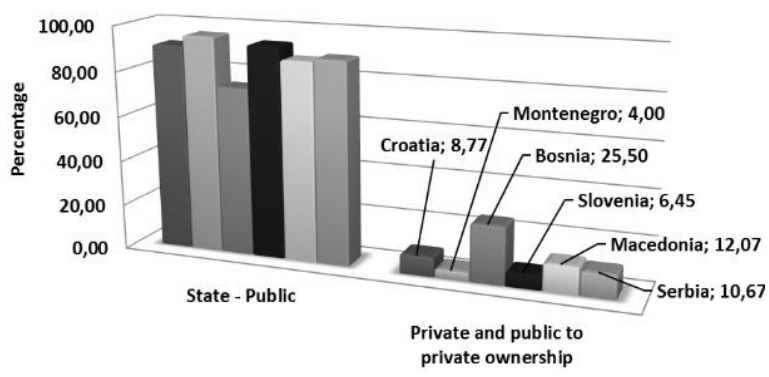

Fig. 1 The ratio of public and private secondary schools

If the order to move in-depth analysis of why it was in Bosnia that a quarter of secondary schools are privately owned, sure that one of the reasons is the fact that for them there is no single legal framework governing the issue of the establishment of private secondary schools. In fact, "founder shall submit a study on the socioeconomic justification for establishing high school" (Decree Law on Institutions, Framework Law on Primary and Secondary Education, Law on Primary Education in Sarajevo Canton, Procedure for the establishment of high school, number: 11-01-38-sl., 2009, Law on Education in Primary and secondary schools of Brcko District of $B \& H)$. The largest number of private secondary schools did not submit the said studies or "studies on the socio-economic justification are for establishing agreements on the establishment, the final decision, with only a few sentences, without explanation or, simply, the theory of what a study should include" (Haskić, 2015). Respectively, each canton and county (total there are 11, plus District Brcko) has its own regulations to some extent legally regulate the establishment of private secondary schools. In the calculation of population are taken data from the official websites of the statistical bureaus of the mentioned countries.

As for the number of children attending private high schools in relation to the number of children in public secondary schools in the first place is Croatia $(3,31 \%$ of children in private schools) (Upper Secondary Schools, End of 2014/2015 School Year and Beginning of 2015/2016 School Year, Croatia, 2016), followed by Slovenia
(2.48\%) (Participants (youth and adults) in public and private upper secondary schools, Slovenia, annually, 2014) i Macedonia (2.80\%) (Primary, lower secondary and upper secondary schools at the begining of the school year 2015/2016, Macedonia, 2016) and finally Serbia with less than two percent of children (1.85\%) (Ministry of Education, Science and Technological Development, Republic of Serbia, 2016) (Figure 2). There are no official statistics for Montenegro and $\mathrm{B} \& \mathrm{H}$.

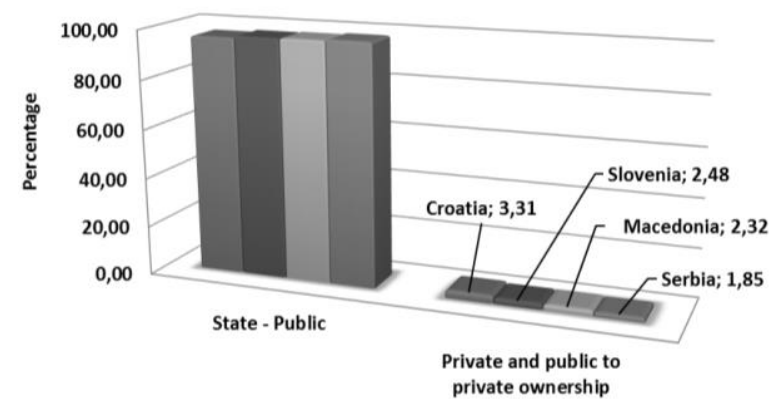

Fig. 2 Pupils-public vs. Private schools

\subsection{Secondary schools - Grammar vs. VET \& Art school}

Looking at the ratio Grammar school and Vocational Education and Training-VET and Art school, it was perceived that Grammar schools constituted 20 to $30 \%$ of the total number of secondary schools. The largest share of VET and Art schools is in B\&H (79.50\%) (Haskić, 2015), Serbia $(74.70 \%)$ (Ministry of Education, Science and Technological Development, Republic of Serbia, 2017) (Municipalities and regions in the Republic of Serbia, 2016 - Education, 2016), Montenegro $(76.00 \%)$ (List of high schools in Montenegro, -), and Croatia (69.58\%) (Upper Secondary Schools, End of 2014/2015 School Year and Beginning of 2015/2016 School Year, Croatia, 2016). Slovenia is specific on this point because in addition to traditional high school there are high school programs within the school centers, and information on the number of high schools is not totally relevant and is not taken in consideration. The number of students at the secondary school programs in Slovenia will be shown, too. For Macedonia, there are no official data on the number of high school or the number of students in high schools and vocational schools.

It is certainly more appropriate to observe the number of students, and their relation to the 
Grammar school and VET \& Art School. In Serbia, even $77.00 \%$ of children attend VET \& Art School (Brolpito, Lightfoot, Radišić, \& Šćepanović, 2016), Croatia 69.58\% (Upper Secondary Schools, End of 2014/2015 School Year and Beginning of 2015/2016 School Year, Croatia, 2016) and Slovenia $62.24 \%$ (Participants (youth and adults) in public and private upper secondary schools, Slovenia, annually 2014) (Figure 3). There are no official data for $\mathrm{B} \& \mathrm{H}$ and Montenegro, therefore, it is not shown.

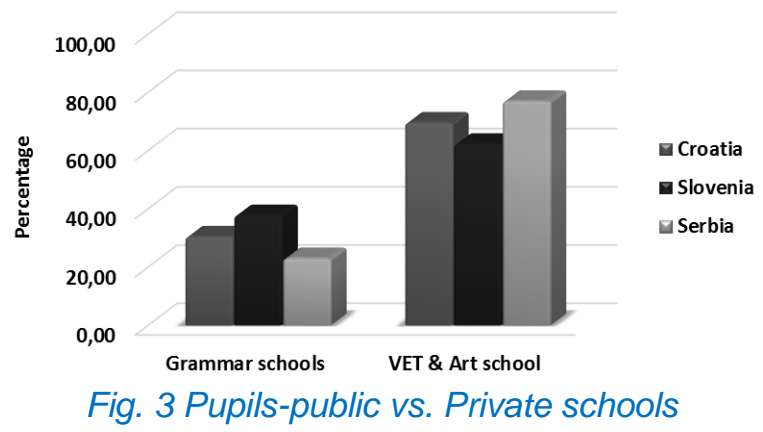

\subsection{Private secondary schools}

The following is a brief speculation of private secondary schools, and which type of secondary school is more prevalent in the private sector, Grammar school or VET \& Art School.

In Croatia, there is a larger number of private Grammar schools (42) than VET \& Art schools (18) (Upper Secondary Schools, End of 2014/2015 School Year and Beginning of 2015/2016 School Year, Croatia, 2016). In other words, $21.21 \%$ of the total number of Grammar school is private, while the VET \& Art school only $3.54 \%$ private.

Moreover, there are only two private high schools in Montenegro, one Grammar school, and the other VET \& Art School. In percentages of total: Grammar school (12) private is $8.33 \%$ and for VET \& Art School it is $2.63 \%$ of the total 38 private schools of this type (List of high schools in Montenegro, -).

The situation in $\mathrm{B} \& \mathrm{H}$ expressed in figures is as follows. There are only 8 private Grammar school which makes $19.51 \%$ compared to the total number of Grammar school, while the other side has 43 private VET \& Art School or $27.04 \%$ compared to the total number of these schools (Haskić, 2015).
The percentage share of private VET \& Art School in Serbia is slightly less than the number of private Grammar schools. In fact, there are $9.29 \%$ of private VET \& Art School (the total number of schools of this type is 452), while the percentage of private Grammar school is $12.50 \%$ (with the total number of Grammar school 128) (Secondary schools, Education, -).

For the other two ex-YU republics (Slovenia and Macedonia) there are no official data on the number of private Grammar and VET and Art school.

So, looking at the percentage share of private schools in relation to their implemented programs, B\&H has the highest percentage of private VET \& Art School (27.04\%), and Croatia the highest percentage of private Grammar school $(21.21 \%)$.

For Croatia, Slovenia and Serbia there are no official figures on the number of children attending private VET \& Art School or Grammar school. The total number of children attending Grammar school in private schools in Croatia is $8.78 \%$, Slovenia $4.09 \%$, while in Serbia only $1.00 \%$. The situation in the private VET \& Art school is significantly different. Slovenia has no private school type VET \& Art School, in Croatia, it is just under one percent of children $(0.91 \%)$, while in Serbia $1.00 \%$ compared to the total number of children attending school in the aforementioned type of school.

\subsection{Ex-YU - private school summary}

Analyzing all the statistical results, it is concluded that in the ex-YU countries the largest number of private secondary schools is situated in Bosnia and Herzegovina (over 25\%), and the lowest in Montenegro, only $4 \%$. Based on the number of children attending private high schools at the first place is Croatia (a little over $3 \%$ ), and last is Serbia (1.85\%), while for Bosnia and Herzegovina and Montenegro are no official data.

Looking at the type of school represented in private secondary education there is no single conclusion. In B\&H, over $27 \%$ of VET \& Art School is a private, while in Croatia, the highest percentage of private goes to Grammar school (a little less than 22\%). It is interesting that in Slovenia doesn`t exist any private VET \& Art School. 
As the EU as far as secondary education has a strategy to VET \& Art school be more represented than Grammar school or that vocational education intensifies, it is clear that changes must occur in the area ex-YU. This certainly gives a new space for the private education business and directs the movement in this part of the private sector.

\section{SECONDARY BUSINESS}

The number of private secondary schools is increasing from year to year, respectively the competition is increasing. The question is how to be well positioned and remain successful in this field of education. Certainly, the quality of the work comes in the first place. Of at least the same importance is the decision of the educational profile that should be emphasized, how to organize teaching, how to establish good interpersonal relationships in a group and the like. The main organ of these activities is the founder and/or a school principal.

In the next part of this paper, it will be discussed the management of the private secondary business.

\subsection{National Qualifications Framework of Serbia}

Starting from the universal fact of world trends in the economy and society, modern high school is required to develop their work and adapt to the demands of their specific environment in terms of realization of a particular education in accordance with the specific needs of the education market. It should take into account the specific educational standards of their country and at the same time fit into the appropriate international educational trends.

In addition to presenting the legal framework relating to the establishment of private high schools, it is necessary to consider the National Qualifications Framework (NQF) and decide which educational profiles should be implemented in the school.

The market demands dictate higher or lower demand for certain jobs. Jobs describe the relevant competencies that prospective employees must possess. The task of NQF is to define the standards of qualification based on these competencies. Each standard qualification is described by the following elements:

- Basic data - name and code of the profession, the required level of education, jobs, and tasks on which employees will work

- Workplace and equipment information - place of supply of interest (eg. office, etc.) And assets (eg., computer, software tool, etc.)

- Competencies - general and more specific competencies and ability

- Education - appropriate educational qualifications and profile specific requests (eg. licenses, certificates, attests...).

The qualification standards are defined by people hired in Economy, industry, the National Employment Service, and the education system. Relevant educational programs which are partially implemented in secondary education are created in accordance with defined standards of qualification.

This is how it should look like the process of creating educational programs. Unfortunately, in practice, sometimes we can see big differences, of the fact that NQF has not been established or has not been revised for many years, despite the fact that the labor market is changing rapidly, to complete non-compliance and obsolescence of educational programs.

\subsection{The lifetime of education business}

The education business is characterized by the fact that the first real results can be seen after one educational cycle. This term is considered to be a period of four-year education, and three years for educational programs which are defined by a three-year education. This further implies the increasing demand for treated educational business, founder (a person who invests capital) must initially take into consideration the negative business to achieve break-even point. Also at the first signs of falling demand for relevant training programs, should be done properly analysis which can show whether to take strategic decisions: start a new cycle (the first grade) or 'shut down' 'the educational program without waiting for the operating result becomes negative (below the break-even point). Partial changes (less or more) also can be done in the educational program, which is expected to decline demand in the market. It should be noted that educational 
programs are defined by the competent ministry and that the adoption of amendments is usually a long process, so the question arises whether to indulge or choose another educational program which is wanted. In making such decisions it should be considered professional work area in which is school already recognized in the market.

Based on the stated speculation, it can be concluded that the key interest of founder is to define a good strategic plan that sets clear straight line and direction of movement of the education business in the longest possible period which longer implies the realization of positive business results.

In this connection, the founder must pay particular attention to the point in time when the yield curve begins to stagnate, which for him is to be a sign of holding your negative business or end life of the treated business. At that moment, the founder would have to intensify efforts on identifying educational program whose implementation should improve treated business or replace it with a more likely market educational programs. Therefore, this analysis should be the basis for evaluation of achieved economic results in the education business.

\section{THE MANAGEMENT OF PRIVATE SECONDARY SCHOOLS}

The management of private secondary schools founders, as owners of the invested capital are the supreme administrative body that brings big, strategic administrative decisions (status, entrepreneurial and other). In contrast, the Director manages the organization and through this function delivers operational control decisions (about the process of work, investing a certain amount, earnings, employment, etc. issues relevant for the functioning of schools).

It is especially important to emphasize that the practice connected to the founders and directors are not harmonized in terms of their competence, but often comes to the overlapping of their activities. Founders are generally interested that through investing capital subordinate their personal interests to the common good. Given that the educational activities are of great importance, founder, except capital investing and obligation to participate in its placement, must have adequate managerial educational competencies.

The practice of managing private secondary schools in the EU predominantly is characterized by following factors (Ristić, 2009): legal regulation of the education system as a whole, the existence of basic standards in the operation of private schools, the unevenness in the field of school management and the vagueness of the competence of the management body.

Founders often form their executive bodies (board) which, because of the greater efficiency of management and leadership, confide their particular jurisdiction. Therefore, the administrative bodies of contemporary organizations make the unity of action of the founder and director, who are together commonly referred to as the administration. Within that, when it comes to school boards, they make the specific executive authority of the founders of the school and their responsibilities are primarily related to the decision on the realization of educational work in school.

\subsection{Research results and their analysis}

The management of private secondary schools has not been explored yet, and therefore there is a lot of practical problems in this area. In such situations management of private schools is necessarily realized in analogous (apparently identical) manner as in public secondary schoolswhere within the school board, the school is managed by certain representatives of the founders, employees, and students' parents. However, such a management model of private secondary schools is unacceptable as it severely limits the rights of the founder, as the subject who has invested capital in the school and that by that logic takes care of the development of the school and settle any losses in the business of the school. In such a situation the legislation power management to private secondary schools is not processed, but by default management solutions to public schools are applied to private schools.

In order to establish a realistic picture, respectively, to show what the opinion of people who are directly engaged in private secondary education is, a survey was conducted by the method of interviewing. The survey was 
anonymous and was conducted on a sample of 60 subjects consisted of the founders of private secondary schools (30 of them) and directors of private secondary schools (30 of them). The respondents were familiar with the object and purpose of the research. The survey was conducted in the Republic of Serbia and carried out in cooperation with the Union of private secondary schools in Serbia.

That legislation is largely ill-defined in the field of private secondary schools considered $55.00 \%$ of respondents (Table 1). By reviewing the Law on Basic Education System of the Republic of Serbia (Law on the Basis of the Education System of the Republic of Serbia, 2015), it was shown that the legislator paid full attention to the educational institutions where the state or the local government is the founder, and for the institution where founder of another legal or natural person left insufficiently regulated.

Table 1. How do you evaluate the current legislative managing to the private high school in Serbia?

\begin{tabular}{|c|c|c|c|}
\hline Respondents & Offered answers & $\begin{array}{l}\text { Number of } \\
\text { answers }\end{array}$ & $\begin{array}{c}\% \\
\text { answers }\end{array}$ \\
\hline \multirow{5}{*}{$\begin{array}{l}\text { A. } \\
\text { Founders of } \\
\text { schools }\end{array}$} & a) mostly good & 2 & 6.70 \\
\hline & b) average & 6 & 20.00 \\
\hline & $\begin{array}{l}\text { c) predominantly } \\
\text { poor }\end{array}$ & 16 & 53.30 \\
\hline & d) not familiar & 6 & 20.00 \\
\hline & $\Sigma$ & 30 & 100.00 \\
\hline \multirow{5}{*}{$\begin{array}{l}\text { B. } \\
\text { School } \\
\text { directors }\end{array}$} & a) mostly good & 2 & 6.60 \\
\hline & b) average & 11 & 36.70 \\
\hline & $\begin{array}{l}\text { c) predominantly } \\
\text { poor }\end{array}$ & 17 & 56.70 \\
\hline & d) not familiar & - & \\
\hline & $\Sigma$ & 30 & 100.00 \\
\hline \multirow{5}{*}{$\begin{array}{l}\text { C. } \\
\text { Total }\end{array}$} & a) mostly good & 4 & 6.70 \\
\hline & b) average & 17 & 28.30 \\
\hline & $\begin{array}{l}\text { c) predominantly } \\
\text { poor }\end{array}$ & 37 & 55.00 \\
\hline & d) not familiar & 6 & 10.00 \\
\hline & $\Sigma$ & 60 & 100.00 \\
\hline
\end{tabular}

The next few questions are about the same stage of the realization of the education business (which was explored in more detail in the previous part of this paper). The goal was to determine how all of these stages carried out in accordance with updated scientific based theoretical assumptions or more are applied subjectively and improvised approach.

When making plans for the development of secondary schools, a half of respondents from the group founders of private schools considered that a modern development planning was a basis for drawing up specific plans for development while the other half believed that improvisation was a better solution. In the case of school directors, the situation is drastic. In fact, $70.00 \%$ of directors conducts improvised development planning, but only $13.30 \%$ of them carries out modern business planning (Table 2).

Table 2. What is the basis of making plans for the development of our private secondary school?

\begin{tabular}{|c|c|c|c|}
\hline Respondents & Offered answers & $\begin{array}{c}\text { Number of } \\
\text { answers }\end{array}$ & $\begin{array}{c}\% \\
\text { answers }\end{array}$ \\
\hline \multirow{5}{*}{$\begin{array}{l}\text { A. } \\
\text { Founders of } \\
\text { schools }\end{array}$} & $\begin{array}{l}\text { a) modern } \\
\text { planning } \\
\text { development }\end{array}$ & 15 & 50.00 \\
\hline & \begin{tabular}{|l} 
b) improvised \\
planning \\
development
\end{tabular} & 15 & 50.00 \\
\hline & $\begin{array}{l}\text { c) subjective } \\
\text { development } \\
\text { planning }\end{array}$ & - & \\
\hline & d) not familiar & - & - \\
\hline & $\Sigma$ & 30 & 100.00 \\
\hline \multirow{5}{*}{$\begin{array}{l}\text { B. } \\
\text { School } \\
\text { directors }\end{array}$} & $\begin{array}{l}\text { a) modern } \\
\text { planning } \\
\text { development }\end{array}$ & 4 & 13.30 \\
\hline & $\begin{array}{l}\text { b) improvised } \\
\text { planning } \\
\text { development }\end{array}$ & 21 & 70.00 \\
\hline & $\begin{array}{l}\text { c) subjective } \\
\text { development } \\
\text { planning }\end{array}$ & - & - \\
\hline & d) not familiar & 5 & 16.70 \\
\hline & $\Sigma$ & 30 & 100.00 \\
\hline \multirow{5}{*}{$\begin{array}{l}\text { C. } \\
\text { Total }\end{array}$} & $\begin{array}{l}\text { a) modern } \\
\text { planning } \\
\text { development }\end{array}$ & 19 & 31.60 \\
\hline & $\begin{array}{l}\text { b) improvised } \\
\text { planning } \\
\text { development }\end{array}$ & 36 & 60.00 \\
\hline & $\begin{array}{l}\text { c) subjective } \\
\text { development } \\
\text { planning }\end{array}$ & - & - \\
\hline & d) not familiar & 5 & 8.40 \\
\hline & $\Sigma$ & 60 & 100.00 \\
\hline
\end{tabular}

Changes by the boards in private schools are mainly carried out on the basis of a subjective 
approach that considers the director $80.00 \%$ or $65.50 \%$ of all respondents (directors and founders) (Table 3 ).

Table 3. Which basis the administrative authorities organize changes in our private high schools on?

\begin{tabular}{|c|c|c|c|}
\hline Respondents & Offered answers & $\begin{array}{l}\text { Number of } \\
\text { answers }\end{array}$ & $\begin{array}{c}\% \\
\text { answers }\end{array}$ \\
\hline \multirow{5}{*}{$\begin{array}{l}\text { A. } \\
\text { Founders of } \\
\text { schools }\end{array}$} & $\begin{array}{l}\text { a) on the basis } \\
\text { of the } \\
\text { Development } \\
\text { Plan }\end{array}$ & 15 & 50.00 \\
\hline & $\begin{array}{l}\text { b) by } \\
\text { improvisation } \\
\text { of the } \\
\text { Development } \\
\text { Plan }\end{array}$ & - & - \\
\hline & $\begin{array}{l}\text { c) based on the } \\
\text { subjective } \\
\text { approach }\end{array}$ & 15 & 50.00 \\
\hline & d) not familiar & - & - \\
\hline & $\Sigma$ & 30 & 100.00 \\
\hline \multirow{5}{*}{$\begin{array}{l}\text { B. } \\
\text { School } \\
\text { directors }\end{array}$} & $\begin{array}{l}\text { a) on the basis } \\
\text { of the } \\
\text { Development } \\
\text { Plan }\end{array}$ & 2 & 6.70 \\
\hline & $\begin{array}{l}\text { b) by } \\
\text { improvisation } \\
\text { of the } \\
\text { Development } \\
\text { Plan }\end{array}$ & - & \\
\hline & \begin{tabular}{|l} 
c) based on the \\
subjective \\
approach \\
\end{tabular} & 24 & 80.00 \\
\hline & d) not familiar & 4 & 13.30 \\
\hline & $\Sigma$ & 30 & 100.00 \\
\hline \multirow{5}{*}{$\begin{array}{l}\text { C. } \\
\text { Total }\end{array}$} & $\begin{array}{l}\text { a) on the basis } \\
\text { of the } \\
\text { Development } \\
\text { Plan }\end{array}$ & 17 & 28.30 \\
\hline & $\begin{array}{l}\text { b) by } \\
\text { improvisation } \\
\text { of the } \\
\text { Development } \\
\text { Plan }\end{array}$ & - & \\
\hline & $\begin{array}{l}\text { c) based on the } \\
\text { subjective } \\
\text { approach }\end{array}$ & 39 & 65.00 \\
\hline & d) not familiar & 4 & 6.70 \\
\hline & $\Sigma$ & 60 & 100.00 \\
\hline
\end{tabular}

In the implementation phase of the education business, the situation is better in terms of applying theoretical approaches recommended. In fact, it applies $50.00 \%$ of the respondents, $28.30 \%$ preferred personally conceived approach, while improvisation conducted $18.30 \%$ of respondents (Table 4).

Table 4. Which principle do managers of our private schools use to manage the realization of treated educational activity?

\begin{tabular}{|c|c|c|c|}
\hline Respondents & Offered answers & $\begin{array}{l}\text { Number of } \\
\text { answers }\end{array}$ & $\begin{array}{c}\% \\
\text { answers }\end{array}$ \\
\hline \multirow{5}{*}{$\begin{array}{l}\text { A. Founders } \\
\text { of schools }\end{array}$} & $\begin{array}{l}\text { a)the theoretical } \\
\text { approach } \\
\text { recommended }\end{array}$ & 15 & 50.00 \\
\hline & $\begin{array}{l}\text { b)the personally } \\
\text { conceived } \\
\text { approach } \\
\text { recommended }\end{array}$ & 8 & 26.70 \\
\hline & $\begin{array}{l}\text { c) improvised } \\
\text { approach }\end{array}$ & 7 & 23.30 \\
\hline & d)not familiar & - & - \\
\hline & $\Sigma$ & 30 & 100.00 \\
\hline \multirow{5}{*}{$\begin{array}{l}\text { B. } \\
\text { School } \\
\text { directors }\end{array}$} & $\begin{array}{l}\text { a)the theoretical } \\
\text { approach } \\
\text { recommended }\end{array}$ & 15 & 50.00 \\
\hline & $\begin{array}{l}\text { b)the personally } \\
\text { conceived } \\
\text { approach } \\
\text { recommended } \\
\end{array}$ & 9 & 30.00 \\
\hline & $\begin{array}{c}\text { c) improvised } \\
\text { approach }\end{array}$ & 4 & 13.30 \\
\hline & d)not familiar & 2 & 6.70 \\
\hline & $\Sigma$ & 30 & 100.00 \\
\hline \multirow{5}{*}{$\begin{array}{l}\text { C. } \\
\text { Total }\end{array}$} & $\begin{array}{l}\text { a)the theoretical } \\
\text { approach } \\
\text { recommended }\end{array}$ & 30 & 50.00 \\
\hline & $\begin{array}{l}\text { b)the personally } \\
\text { conceived } \\
\text { approach } \\
\text { recommended }\end{array}$ & 17 & 28.30 \\
\hline & $\begin{array}{l}\text { c) improvised } \\
\text { approach }\end{array}$ & 11 & 18.30 \\
\hline & d)not familiar & 2 & 3.40 \\
\hline & $\Sigma$ & 60 & 100.00 \\
\hline
\end{tabular}

During the valuation of the results of operations personally conceived approach applies $50.00 \%$ of the respondents, $38.30 \%$ preferred theoretical recommended approach, while improvisation implemented $11.70 \%$ of respondents (Table 5 ).

Based on the results can be concluded that a total of four stages in the realization of the education business, the administrative authorities of schools (school founders and directors) only at the stage of implementation apply the theoretical recommended approach, while in the other three phases rely on personal feeling and subjective approach. 
Table 5. Which approach do administrative authorities of our private secondary schools use in the evaluation of the results of business?

\begin{tabular}{|c|c|c|c|}
\hline Respondents & Offered answers & $\begin{array}{c}\text { Number of } \\
\text { answers }\end{array}$ & $\begin{array}{c}\% \\
\text { answers }\end{array}$ \\
\hline \multirow{5}{*}{$\begin{array}{l}\text { A. Founders } \\
\text { of schools }\end{array}$} & $\begin{array}{l}\text { a)the theoretical } \\
\text { approach } \\
\text { recommended }\end{array}$ & 8 & 26.60 \\
\hline & $\begin{array}{l}\text { b)the personally } \\
\text { conceived } \\
\text { approach } \\
\text { recommended }\end{array}$ & 15 & 50.00 \\
\hline & $\begin{array}{l}\text { c) improvised } \\
\text { approach }\end{array}$ & 7 & 23.40 \\
\hline & d)not familiar & - & - \\
\hline & $\Sigma$ & 30 & 100.00 \\
\hline \multirow{5}{*}{$\begin{array}{l}\text { B. } \\
\text { School } \\
\text { directors }\end{array}$} & $\begin{array}{l}\text { a)the theoretical } \\
\text { approach } \\
\text { recommended }\end{array}$ & 15 & 50.00 \\
\hline & $\begin{array}{l}\text { b)the personally } \\
\text { conceived } \\
\text { approach } \\
\text { recommended } \\
\end{array}$ & 15 & 50.00 \\
\hline & \begin{tabular}{|c|} 
c) improvised \\
approach
\end{tabular} & - & - \\
\hline & d)not familiar & - & - \\
\hline & $\Sigma$ & 30 & 100.00 \\
\hline \multirow{5}{*}{$\begin{array}{l}\text { C. } \\
\text { Total }\end{array}$} & $\begin{array}{l}\text { a)the theoretical } \\
\text { approach } \\
\text { recommended }\end{array}$ & 23 & 38.30 \\
\hline & $\begin{array}{l}\text { b)the personally } \\
\text { conceived } \\
\text { approach } \\
\text { recommended } \\
\end{array}$ & 30 & 50.00 \\
\hline & $\begin{array}{l}\text { c) improvised } \\
\text { approach }\end{array}$ & 7 & 11.70 \\
\hline & d)not familiar & - & - \\
\hline & $\Sigma$ & 60 & 100.00 \\
\hline
\end{tabular}

In terms of management competence of administrative organs, $70.00 \%$ of the surveyed directors believe that he is mostly intermediate level, while the founders of the school are equally divided between thinking that the administrative authorities of schools have a middle and high level of management competence (Table 6).

It can be said for the current survey $s$ that it is representative, as it involved 30 control boards of private schools or $58.8 \%$ of the total number of private secondary schools in the Republic of Serbia, and therefore the results are important for the conclusion.
Table 6. What average level management competencies have administrative authorities of our private secondary schools?

\begin{tabular}{|c|c|c|c|}
\hline Respondents & Offered answers & $\begin{array}{l}\text { Number of } \\
\text { answers }\end{array}$ & $\begin{array}{c}\% \\
\text { answers }\end{array}$ \\
\hline \multirow{5}{*}{$\begin{array}{l}\text { A. Founders } \\
\text { of schools }\end{array}$} & $\begin{array}{l}\text { a) mostly high } \\
\text { level }\end{array}$ & 15 & 50.00 \\
\hline & $\begin{array}{l}\text { b) mostly } \\
\text { average level }\end{array}$ & 15 & 50.00 \\
\hline & $\begin{array}{l}\text { c) mostly low } \\
\text { level }\end{array}$ & - & - \\
\hline & e) not familiar & - & - \\
\hline & $\Sigma$ & 30 & 100.00 \\
\hline \multirow{5}{*}{$\begin{array}{l}\text { B. } \\
\text { School } \\
\text { directors }\end{array}$} & $\begin{array}{l}\text { a) mostly high } \\
\text { level }\end{array}$ & 6 & 20.00 \\
\hline & $\begin{array}{l}\text { b) mostly } \\
\text { average level }\end{array}$ & 21 & 70.00 \\
\hline & $\begin{array}{l}\text { c) mostly low } \\
\text { level }\end{array}$ & - & - \\
\hline & e) not familiar & 3 & 10.00 \\
\hline & $\Sigma$ & 30 & 100.00 \\
\hline \multirow{5}{*}{$\begin{array}{l}\text { C. } \\
\text { Total }\end{array}$} & $\begin{array}{l}\text { a) mostly high } \\
\text { level }\end{array}$ & 21 & 35.00 \\
\hline & $\begin{array}{l}\text { b) mostly } \\
\text { average level }\end{array}$ & 36 & 60.00 \\
\hline & $\begin{array}{l}\text { c) mostly low } \\
\text { level }\end{array}$ & - & \\
\hline & e) not familiar & 3 & 5.00 \\
\hline & $\Sigma$ & 60 & 100.00 \\
\hline
\end{tabular}

\section{CONCLUSION}

Starting from the universal fact exposed to global trends in the economy and society, modern high schools are required to develop their work and adapt to the demands of their specific environment in terms of realization of a particular education in accordance with the specific needs of the education market. Private high schools should take into account the specific educational standards of their country and at the same time fit into the appropriate international educational trends. The main implications of modern developments in the legal regulation of business high school come down to its principled equality with other business entities, except that it takes into account the specificity of the core business schools, as well as activities of special public interest. However, when it comes to the 
management of secondary education, it is in principle identical to the management of any other undertaking. It is, in fact, on what all of them are managed by the competent management authorities which include founder and CEO.

The status of private education in the EU and countries in transition, according to their experience, cannot be regarded as a clear and definite, that is, can not be accepted as a single model or a model that could be applied universally. During the search form and functioning of private education EU countries went to specific mutually different paths. However the common understanding of private education as an alternative and complementary state sector in most countries.

Therefore, it is necessary to legally regulate the internal management of private high schools just like the regulatory management of all market- orientated organizations. Thereat must be respected the specificity of private secondary schools, as well as educational institutions, have the character of an organization of special public interest. Therefore, all its management factors (administrative authorities, administrative authorities and the competence of administrative authorities) must be implicitly tied to the essence and importance of educational activities. In addition, this implies the need for standardization and implementation of permanent education for holders of administrative functions (in particular: the director, president of the school board and president of Assembly of the founder), since it greatly affects the time to raise their administrative competence of - which consequently contributes to the performance of work and the development of private and public high schools.

\section{WORKS CITED}

Brolpito, A., Lightfoot, M., Radišić, J., \& Šćepanović, D. (2016). Digital and Online learning in Vocational Education and Training in Serbia - A case study. European Training Foundation ETF.

Directory of secondary schools in the Federation of Bosnia and Herzegovina. (2012, July). Retrieved on March 2016 from The Federal Ministry of Education and Science of the Federation of Bosnia and Herzegovina:

http://www.fmon.gov.ba/index.php?option=com_content\&view=article\&id=213:adresarsrednjih-kola-u-federaciji-bosne-i-hercegovine\&catid=39:sektor-za-predkolsko-osnovno-isrednje-obrazovan\&ltemid=150\#sthash.7Olo6uvH.dpuf

Haskić, I. (2015). Privatne škole u Bosni i Hercegovini. Retrieved on March 2016 from Školegijum, Magazin za pravedno obrazovanje: http://skolegijum.ba/static/biblioteka/567c138f02c25_privatneskoleubosniihercegovini.pdf

List of high schools in Montenegro. (-). Retrieved on March 2017 from Ministry of Education, Republic of Montenegro:

http://www.mpin.gov.me/ResourceManager/FileDownload.aspx ?rld=209740\&rType=2

Ministry of Education, Science and Technological Development, Republic of Serbia. (2017). Retrieved on March 2017 from http://www.mpn.gov.rs

Municipalities and regions in the Republic of Serbia, 2016 - Education. (2016, December 26). Retrieved on March 2017 from Statistical Office of the Republic of Serbia: http://www.stat.gov.rs/WebSite/repository/documents/00/02/36/42/16._Obrazovanje.pdf

Okvirni zakon o osnovnom i srednjem obrazovanju (eng. Framework Law on Primary and Secondary Education). (n.d.). Službeni glasnik BiH, broj: 18/03.

Participants (youth and adults) in public and private upper secondary schools, Slovenia, annually (2014). Retrieved on March 2017 from Statistical Office Republic of Slovenia: http://pxweb.stat.si/pxweb/dialog/varval.asp?ma=H102E\&ti=\&path=\%2E\%2E\%2FDatabase $\% 2 \mathrm{FHitre} \_$Repozitorij\%2F\&xu=\&yp=\&lang=1 
Postupak osnivanja srednje škole (Procedure for the establishment of high school), number: 11- 0138-sl. (2009, March 16). Sarajevo.

Primary, lower secondary and upper secondary schools at the begining of the school year 2015/2016, Macedonia. (2016, May). Retrieved on March 2017 from Statistical Review: Population and Socila Statistics, No: 2.4.16.05-850, State Statistical Office, Republic of Macadonia: http://www.stat.gov.mk/Publikacii/2.4.16.05.pdf

Ristić, B. (2009). Upravljanje razvojem privatne srednje škole (Doctoral dissertation). Novi Pazar: doktorska disertacija, Univerzitet u Novom Pazaru.

Srednje škole, Edukacija. (-). Retrieved on March 2017 from http://srednjeskole.edukacija.rs

Upper Secondary Schools, End of 2014/2015 School Year and Beginning of 2015/2016 School Year, Croatia. (2016, April 26). Retrieved on March 2017 from Croation Bureau of Statistics: http://www.dzs.hr/Hrv_Eng/publication/2016/08-01-03_01_2016.htm

Uredba sa zakonskom snagom o ustanovama (Decree Law on Institutions). (n.d.). Službeni glasnik $\mathrm{BiH}$, broj: 6/92, 8/93, 13/94.

Zakon o obrazovanju u osnovnim i srednjim školama Brčko distrikta BiH (Law on Education in Primary and secondary schools of Brcko District of $\mathrm{BiH}$ ). (n.d.).

Zakon o osnovama sistema obrazovanja i vaspitanja Republike Srbije (eng. Law on the Basis of the Education System of the Republic of Serbia). (2015). "SI. glasnik RS", br. 72/2009, 52/2011, 55/2013, 35/2015 - autentično tumačenje i 68/2015.

Zakon o osnovnom obrazovanju Kantona Sarajevo (Law on Primary Education in Sarajevo Canton). (n.d.). Službene novine Kantona Sarajevo, broj 01-02-13276/04.

Received for publication: $\quad 16.12 .2017$

Revision received: $\quad 28.12 .2017$

Accepted for publication: $\quad 10.01 .2018$

\section{How to cite this article?}

Style - APA Sixth Edition:

Ristic, B., Andjelic, S., \& Kuleto, V. (2018, Jan 15). Private secondary education in the ex-YU countries and management practice in private secondary schools. (Z. Cekerevac, Ed.) MEST Journal, 6(1), 79-89. doi:10.12709/mest.06.06.01.09

Style - Chicago Sixteenth Edition:

Ristic, Bojan, Svetlana Andjelic, and Valentin Kuleto. 2018. "Private secondary education in the ex-YU countries and management practice in private secondary schools." Edited by Zoran Cekerevac. MEST Journal (MESTE) 6 (1): 79-89. doi:10.12709/mest.06.06.01.09.

Style - GOST Name Sort:

Ristic Bojan, Andjelic Svetlana and Kuleto Valentin Private secondary education in the ex-YU countries and management practice in private secondary schools [Journal] // MEST Journal / ed. Cekerevac Zoran. - Toronto : MESTE, Jan 15, 2018. - 1 : Vol. 6. - pp. 79-89.

Style - Harvard Anglia:

Ristic, B., Andjelic, S. \& Kuleto, V., 2018. Private secondary education in the ex-YU countries and management practice in private secondary schools. MEST Journal, 15 Jan, 6(1), pp. 79-89.

Style - ISO 690 Numerical Reference:

Private secondary education in the ex-YU countries and management practice in private secondary schools. Ristic, Bojan, Andjelic, Svetlana and Kuleto, Valentin. [ed.] Zoran Cekerevac. 1, Toronto : MESTE, Jan 15, 2018, MEST Journal, Vol. 6, pp. 79-89. 